\title{
EAl Endorsed Transactions

\section{Smart University: A Premise for Regional Development. Evidence from South-East Region of Romania}

\author{
G. Marchis ${ }^{1, *}$ \\ ${ }^{1}$ Danubius University of Galati, Blvd. Galati no.3, 800654, Romania
}

\section{Abstract}

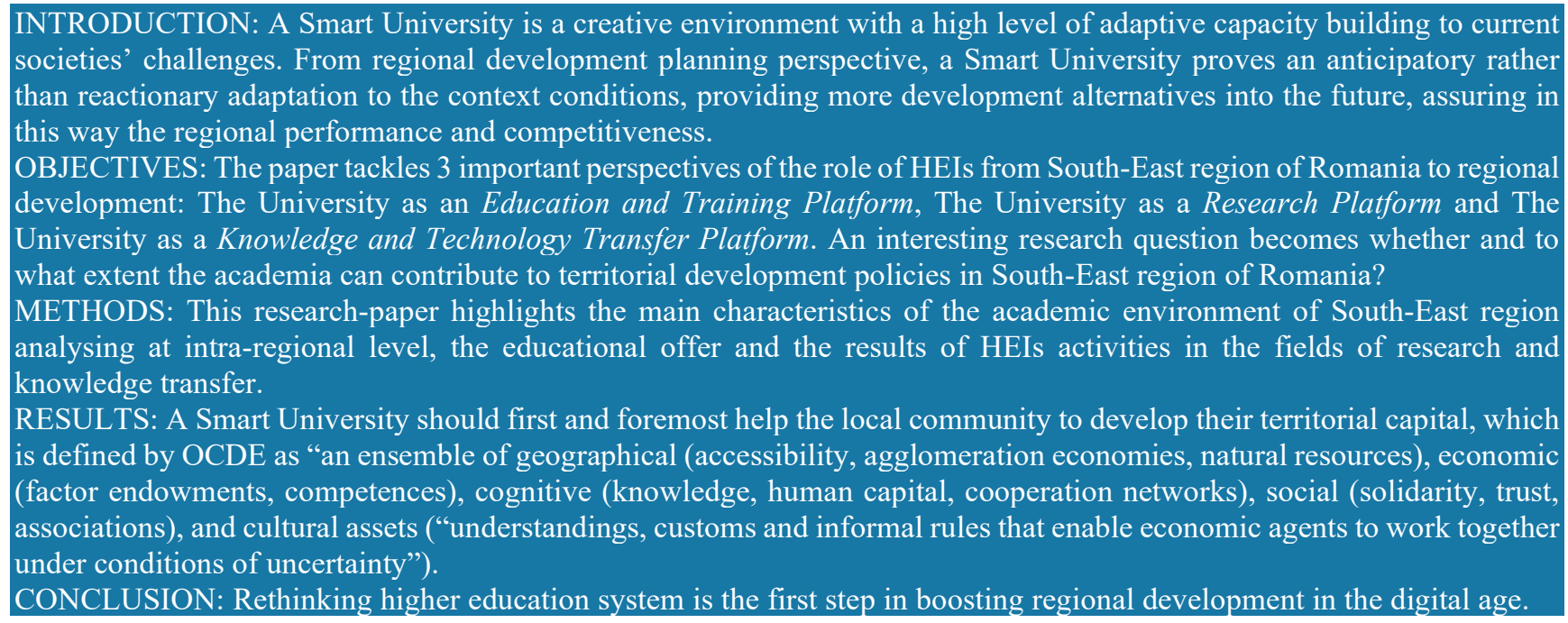

Keywords: innovation, career development, e-platform.

Received on 31 August 2020, accepted on 17 March 2021, published on 19 March 2021

Copyright $(\mathcal{C} 2021 \mathrm{G}$. Marchis et al., licensed to EAI. This is an open access article distributed under the terms of the Creative Commons Attribution license, which permits unlimited use, distribution and reproduction in any medium so long as the original work is properly cited.

doi: 10.4108/eai.19-3-2021.169035

\section{Smart University - A Portal to the Future}

Higher education institutions (HEIs) are the meeting and mediation point between business, public administration and civil society, creating favourable premises for the development of innovative methods, products and services designed to manage the territorial impact of globalization and digitization. Consequently, the Smart University generically presents itself as a training provider, research centre, technology platform in partnership with the regional community whose values and interests it represents. Nowadays, because of new trend of digital

*Corresponding author. Email: gabrielamarchis@univ-danubius.ro transformation of industry and urbanism, Smart University is needed in order to promote the knowledge-based economy at local and regional level.

\section{The South-East Region's Universities, an Unexploited Source for Regional Development}

The South-East Region of Romania faces a number of long-term challenges, such as: aging population, adapting to the digital era, maintaining competitiveness in a globalized and knowledge-based economy. In this context, economic recovery and sustainable growth can be achieved by: reducing investment deficits, creating jobs and 
prioritizing migration flows. All these measures imply an integrated strategic thinking on long-term regional development and the active participation of all relevant actors in the region: public authorities, business, catalysts organizations, universities, etc. Coordinating the efforts of all relevant stakeholders at the level of the South-East region can be the attribute of the university environment.

The role of universities in the South East region in terms of regional development is bivalent. On the one hand, high quality education and training provided by higher education institutions active in the region contributes to promoting sustainable economic growth and sustainable development, fuelling $\mathrm{R} \& \mathrm{D}$, innovation, productivity and competitiveness, and on the other hand, the university environment, as a space for the transfer of knowledge, innovation and technology, as well as the interaction of all relevant actors with potential in the regional development process, can develop integrated socio-economic development strategies to improve efficiency and the effectiveness of isolated measures implemented by different public and private entities.

In the following, we will analyse the state of development of higher education in South-East region and the extent of the added value that the university environment can bring to regional development.

\subsection{University - as Education and Training Platform}

University education in the South-East region of Romania is carried out in higher education institutions, public and private, the main university centres being the counties of Constanta and Galati.

Constanta County is the largest university centre in the South-East region. Here, the didactic and research activities take place in the public sector within the "Ovidius" University of Constanta (16 faculties), the Constanţa Maritime University (2 faculties) and the "Mircea cel Bătrân" Naval Academy in Constanţa (2 faculties), and in the private sector under the aegis of "Andrei Şaguna" University of Constanţa (4 faculties) and "Gaudeamus" Foundation - "Tomis" University of Constanţa.

In Galați County, higher education is represented in the public sector by the "Dunărea de Jos University of Galati", which has 14 faculties, but at the Trans-frontier Faculty the didactic activities take place in Moldova, at Cahul and Chișinău, and at the Faculty of Engineering and Agronomy in Brăila, didactic activities take place in Brăila County. Also, at the Faculty of Medicine and Pharmacy there are two specializations, provisionally authorized (General Nursing and Medicine), where the didactic activity takes place in Italy, at Enna. Higher education in Galati County is represented in the private sector by "Danubius University of Galati", which has 3 faculties.

There are also faculties functioning as branches without legal personality of the universities that have students enrolled in the South-East' counties, but without having hired teaching staff from that county, this coming from universities in the region or outside the region. Thus, in Braila County there are two faculties: the Faculty of Engineering and Agronomy in Braila under the aegis of the "Dunărea de Jos University of Galati" and the Faculty of Management, Marketing in Economic Affairs of Braila under the aegis of "Constantin Brâncoveanu University of Piteşti"; in Buzau County there are: the Faculty of Psychology and Educational Sciences of the "University of Bucharest", the Faculty of Finance, Insurance, Banks and Stock Exchanges under the aegis of the "Academy of Economic Studies of Bucharest" and two faculties within the "Bioterra University in Bucharest" - The Faculty of Agritourism Management in Buzau and the Faculty of Control and Expertise of Food Products in Buzau; Constanta County operates the Faculty of Juridical Sciences and Economics under the aegis of "Spiru Haret University of Bucharest"; Tulcea County operates the Faculty of Agroalimentary and Environmental Economics of the "Academy of Economic Studies of Bucharest", and two faculties operate in Vrancea County: the Faculty of Psychology and Education Sciences under the aegis of the "University of Bucharest" and the Faculty of Management Agritourism from Focsani under the aegis of "Bioterra University of Bucharest". Galati County is the only university center in the South-East region where there are no branches of other universities.

The offer of national higher education system in SouthEast region is structured into 58 bachelor domains, where they gather 182 bachelor's degree programs. In the academic year 2018-2019, the maximum number of students who can be enrolled in the first year in the public higher education system is 12325 .

The offer of private higher education institutions in the South-East region covers 12 bachelor domains where 39 bachelor's degree programs are available. In the academic year 2018-2019, the maximum number of students that can be enrolled in the first year in the private higher education system is 3220 .

The size of the tuition capacity at the level of each degree program is determined by the regular external evaluation processes (once every 5 years) usually performed by ARACIS (The Romanian Agency for Quality Assurance in Higher Education), and is often higher than the demand.

In the current academic year, at the level South-East region, 13150 seats are available in frequency education (IF), of which 10705 in the public system and 2445 in the private system. 1520 seats are available in low-frequency education (IFR), of which 1170 seats in the public system and 350 in the private sector. The maximum number of students enrolled in distance learning (ID) is 875 of which 450 in the public system and 425 in the private system.

At the intra-regional level, the distribution by county of the tuition number for the academic year 2018-2019 is as follows:

- 860 seats are available in Braila County, out of which 350 in the public system and 510 in the private system; 
660 seats are allocated to the frequency form of education and 200 seats for low-frequency education; distance learning is not represented at the county level;

- 200 seats are available in Buzau County, equally distributed between public and private system; 150 seats are allocated to the form of education with frequency and 50 seats for distance learning; lowfrequency education is not represented at county level;

- 8420 seats are available in Constanta County, out of which 7060 in the public system and 1390 in the private system; 7085 seats are allocated to the form of education with a frequency, 1110 seats for lowfrequency education and 225 for distance learning;

- 5855 seats are available in Galati County, out of which 4695 in the public system and 1160 in the private system; 5145 seats are allocated to the form of education with a frequency, 210 seats for lowfrequency education and 500 for distance learning;

- in Tulcea County there are only 100 seats available in the public system for distance learning; private education is not represented at the level of the county;

- 110 seats are available in Vrancea County, out of which 50 in the public system and 60 in the private system; all 110 places are allocated to the form of education with frequency.

The hierarchy of public HEIs in the South-East region, after the tuition number for the academic year 2018-2019, is as follows: "Ovidius University of Constanta" - 5070 seats; "Dunarea de Jos University of Galati" - 5045 seats; "Maritime University of Constanta" - 1245 seats; "Mircea Cel Bătrân" Naval Academy from Constanta - 715 seats; "Academy of Economic Studies of Bucharest" - 150 seats and "University of Bucharest" - 100 seats.

The hierarchy of HEIs in the private system after the tuition number for the academic year 2018-2019, in the South-East region is as follows: "Danubius University of Galati" - 1160 seats; "Andrei Şaguna University of Constanta" - 805 seats; "Constantin Brâncoveanu University of Pitesti" - 510 seats; "Spiru Haret University of Bucharest" - 335 seats; "Gaudeamus Foundation Tomis University of Constanta" - 250 seats; "Bioterra University of Bucharest" - 160 seats.

Summarizing, the educational offer in the South-East region is concentrated in 7 higher education institutions, of which 5 are located in Constanta County and 2 in Galati County. The educational offer is supplemented by the presence in the region of faculties belonging to higher education institutions outside the South-East region. Thus, cumulatively, at the level of the South-East region, there are about 50 faculties.

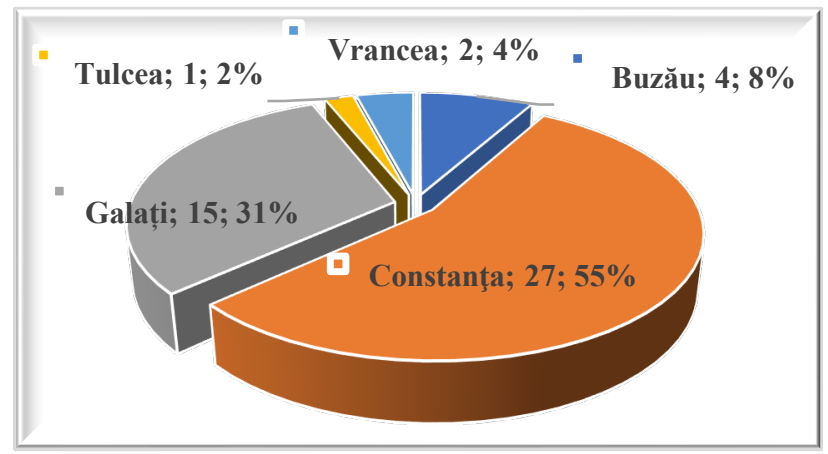

Figure 1. Intra-regional distribution of faculties operating in the South-East region in 2018-2019 academic year

From the perspective of the bachelor domains available in the university offer for 2018-2019 academic year, at the level of the South-East region, we note a monopoly situation for the state HEIs in the following fields of study: Agronomy; Naval Architecture; Visual Arts; Social Assistance; Biology; Biotechnology; Computers and Information Technology; Chemistry; Cybernetics, Statistics and Economic Informatics; Economy; Economics and International Affairs; Physical Education and Sport; Philosophy; Physics; Geography; Horticulture; Informatics; Motor Vehicle Engineering; Materials Engineering; Environmental Engineering; System Engineering; Chemical Engineering; Civil Engineering; Electrical Engineering; Electronic Engineering, Telecommunication and Information Technologies; Energy Engineering; Industrial Engineering; Marine Engineering and Navigation; Mechanical Engineering; Engineering and Management; History; Physical Therapy; Language and Literature; Modern Applied Languages; Math; Mechatronics and Robotics; Music; Health; Sociology; Cultural Studies; Environmental Science; Education Sciences; Applied Engineering Sciences; Political Sciences; Theatre and Performing Arts; Theology; and Zootechnics.

\subsection{University - as Research Platform}

The development of advanced, fundamental and applied research in higher education institutions in the South-East region is carried out on several levels: within the master's programs, within doctoral schools, research centres and aims, inter alia, the development of scientific cooperation internationally, including by stimulating participation in programs of research, development and innovation at international level.

At the level of the South-East region, master programs are present in all counties except in Tulcea County. Most of the master's degree programs are found in the counties of Constanta and Galati with 88 specializations each, which have a capacity of tuition for the academic year 2018-2019, of 5455 students and 3480 students respectively. In Braila County there are 5 master degree programs available for 
this academic year, with a total of 250 seats. In the counties of Buzau and Vrancea, there is only the "University of Bucharest", which has in the current educational offer only the master's domain "Education Sciences", where up to 50 students can be enrolled in each county.

Of the total of 183 master university programs, active in the South-East region, $83.6 \%$ belong to the public education system and only $16.4 \%$ to the private sector.

At the intraregional level, the distribution by county of the tuition number for the master's programs in the academic year 2018-2019 is as follows:

- 250 seats are available in Braila County, out of which 100 in the public system and 150 in the private system;

- 50 seats are available in Buzau County in the public system, the private system being not represented;

- 5455 seats are available in Constanta County, out of which 4950 in the public system and 505 private system;

- 3480 seats are available in the Galati County, out of which 2780 in the public system and 700 in the private system;

- 50 seats are available in Vrancea County in the public system, and the private system is not represented.

Table 1. Regional distribution of master programs for the academic year 2018-2019

\begin{tabular}{|c|c|c|}
\hline & \multicolumn{2}{|c|}{ TOTAL } \\
\hline & $\begin{array}{c}\text { Master degree } \\
\text { programs }\end{array}$ & Available seats \\
\hline \multirow{8}{*}{$\begin{array}{c}\text { South-East } \\
\text { region } \\
\text { Braila } \\
\text { Buzău } \\
\text { Constanţa } \\
\text { Galați } \\
\text { Tulcea } \\
\text { Vrancea }\end{array}$} & 183 & 9285 \\
\hline & 5 & 250 \\
\hline & 1 & 50 \\
\hline & 88 & 5455 \\
\hline & 88 & 3480 \\
\hline & 0 & 0 \\
\hline & 1 & 50 \\
\hline & \multicolumn{2}{|c|}{ Public System } \\
\hline \multirow{8}{*}{$\begin{array}{c}\text { South-East } \\
\text { region } \\
\text { Braila } \\
\text { Buzău } \\
\text { Constanţa } \\
\text { Galați } \\
\text { Tulcea } \\
\text { Vrancea }\end{array}$} & 153 & 7930 \\
\hline & 2 & 100 \\
\hline & 1 & 50 \\
\hline & 77 & 4950 \\
\hline & 72 & 2780 \\
\hline & 0 & 0 \\
\hline & 1 & 50 \\
\hline & \multicolumn{2}{|c|}{ Private System } \\
\hline \multirow{7}{*}{$\begin{array}{c}\text { South-East } \\
\text { region } \\
\text { Braila } \\
\text { Buzău } \\
\text { Constanţa } \\
\text { Galați } \\
\text { Tulcea } \\
\text { Vrancea }\end{array}$} & 30 & 1355 \\
\hline & 3 & 150 \\
\hline & 0 & 0 \\
\hline & 11 & 505 \\
\hline & 16 & 700 \\
\hline & 0 & 0 \\
\hline & 0 & 0 \\
\hline
\end{tabular}

From the perspective of the master domains available in the university offer at the level of the South-East region, we note a monopoly situation for the public HEIs in the following fields: Agronomy; Naval Architecture; Visual Arts; Biology; Biotechnology; Computers and Information Technology; Chemistry; Economy; Economics and International Affairs; Philology; Philosophy; Physics; Geography; Informatics; Economic Informatics; Materials Engineering; Environmental Engineering; Engineering of Food Products; System Engineering; Chemical Engineering; Civil Engineering and Installations; Electrical Engineering; Electronic Engineering, Telecommunication and Information Technologies; Industrial Engineering; Mechanical Engineering; Environmental Engineering; Naval Engineering and Navigation; Engineering and Management; Engineering and Management in Agriculture and Rural Development; History; Marketing; Math; Medicine; Music; Environmental Science; Science of Sport and Education; Administrative Sciences; Education Sciences; Applied Engineering Sciences; Theatre and Performing Arts; and Theology.

The Master's domain "International Relations and European Studies" appears only in the educational offer of the private system, at "Danubius University of Galati". We mention that all master programs in the South-East region are carried out in the form of frequency education (IF), with the exception of the Master's program "Law and European Public Administration" offered by "Danubius University of Galati", where there is also the form of education with lowfrequency education (IFR).

The hierarchy of the public HEIs in the South-East region, after the educational offer for the master level is as follows: "Ovidius University of Constanta" - 4075 seats; "Dunarea de Jos University of Galati" - 2880 seats; "Maritime University of Constanta" - 725 seats; "Mircea cel Bătrân" Naval Academy in Constanţa" - 150 seats; and the "University of Bucharest" - 100 places.

The hierarchy of private HEIs in the South-East region, after the educational offer for the master level is as follows: "Danubius University of Galati" - 700 places; "Andrei Şaguna University of Constanţa" - 250 places; "Constantin Brâncoveanu University of Pitesti" - 150 places; "Spiru Haret University of Bucharest" - 255 places.

\subsection{University - as Knowledge and Technology Transfer Platform}

Advanced research is concentrated in the South-East region in the two large state university centers, in the counties of Constanta and Galati.

In Constanta County, 4 doctoral schools are organized within "Ovidius University", which includes $8 \mathrm{PhD}$ areas, as follows: Doctoral School of Humanities: with the fields of Philology and History; Doctoral School of Applied Sciences with the following fields: Biology, Mathematics and Civil Engineering and Installations; Doctoral School of Medicine with the fields: Medicine and Dentistry; Doctoral 
School of Theology with the field of Theology; and at the "Constanta Maritime University", there is a Doctoral School in Mechanical Engineering and Mechatronics with the fundamental field of Engineering Sciences.

In Galati County, doctoral studies are conducted within 3 multidisciplinary doctoral schools operating under the auspices of the "Dunarea de Jos University of Galati": Doctoral School of Mechanical and Industrial Engineering: with the fields of Mechanical Engineering and Industrial Engineering; Doctoral School of Fundamental and Engineering Sciences: with the fields of Food Engineering, Biotechnologies, Systems Engineering, Electrical Engineering, Computers and Information Technology, Materials Engineering, Engineering and Management in Agriculture and Rural Development and Chemistry; and Doctoral School of Socio-Human Sciences with the following fields: Economics, Management, Philology and History.

In order to get the most complete picture of the R \& D activity in the South-East region, we will also analyse the results reported by these institutions for the period March 2017 - March 2018 on this segment of interest. Based on art.130 paragraph (2) of the National Education Law no. $1 / 2011$, with the subsequent modifications and completions, the results of the research activities for each academic year, are recorded at the level of each Romanian HEIs in the Annual Report of the Rector on the State of University and brought to the attention of stakeholders by publication on the institution's website. (Please note that at the time of writing this research paper, the two private HEIs, active in Constanta County, did not publish this information on their own sites. For this reason, we will synthetically present the research activity in Constanta County, limiting only to the available information.)

\section{Ovidius University in Constanţa}

The scientific research, technological development and innovation activity of "Ovidius University in Constanţa" is recognized internationally. This institution ranks $18^{\text {th }}$ in the QS University Rankings hierarchy at Romania level and $250^{\text {th }}$ in the QS University Rankings hierarchy for the Emerging Europe and Central Asia (EECA) countries: (https://www.topuniversities.com/universityrankings/eeca -rankings/2018).

In the last available hierarchy for 2017, Scimago Institutions Ranking has ranked "Ovidius University in Constanta" on the $20^{\text {th }}$ place between the Romanian HEIs (http://www.scimagoir.com/rankings.php?country=ROU \&year=2017).

In another hierarchy that analyzes Romanian universities, University Ranking by Academic Performance, "Ovidius University in Constanta", is included in category $\mathrm{B}$, ranking $17^{\text {th }}$ nationwide and $2447^{\text {th }}$ position worldwide (http://www.urapcenter.org/2017/country.php?ccode=RO \&rank=all).

The results of the research activity were materialized through the publication of 213 scientific papers, indexed in the Web of Science database (Clarivate Analytics, formerly
ISI) of which: 157 articles; 52 proceedings papers; 4 reviews; 6 meeting abstracts; 3 book chapters.

Another scientometric indicator relevant to the impact of research is the number of citations in Web of Science indexed journals, of articles published by affiliated teaching and research staff, reaching the value of 1216 in 2017.

Regarding the number and value of grants earned by researchers of "Ovidius University in Constanta", in the year 2017, an international project was won, the equivalent value in lei being 407724 and 14 national projects totaling 811278 lei.

"Ovidius University in Constanta", through various research teams, is a member of cluster associations, as follows: the MEDGreen Cluster to promote ecotechnology and alternative energy business (http://www.medgreen.eu); the Danubius-Black Sea Cluster (3D-BS) for the sustainable development of the coastal area and the neighboring regions by exploiting the results of research conducted in the future Danubius-RI Advanced International Center for Advanced Studies; INOMAR Cluster to stimulate innovation in tourism (http://www.inomar.ro/); the DRIFMAT Cluster a distributed research infrastructure for materials, applications and technologies of the future; moreover, it is the initiator in creating an artistic cluster, inspired by INOMAR, a process that is underway.

\section{Maritime University of Constanta}

The survey of the research community of the "Maritime University of Constanta" (UMC) between March 2017 and March 2018 summarizes:

- 10 ongoing projects, out of which 3 industrial research projects;

- 17 new research projects submitted, in different stages of evaluation or contracting;

- publication of 46 scientific papers, out of which: 5 ISI articles (Category A) and 12 indexed ISI Proceedings papers; $25 \mathrm{BDI}$ articles; 1 article published in national specialized journals recognized by CNCSIS (category B); 3 books published in publishers recognized by CNCSIS;

- ICT research infrastructure, developed and sustained with UMC's own resources: management system for university research and innovation activities (management of projects and university research resources https://campus.cmu-edu.eu; cloudcomputing https://docman.cmu-edu.eu ondemand, research performance reporting https: / /owncloud.cmu-edu.eu, document management https://research.cmu-edu.eu); the UMC Research Portal http://research.cmu-edu.eu - provides multicriteria information on research and integrates innovation and development platforms; Virtual Center for Cyber Security Research and Information in the Maritime Cybernetics https://www.maritimecybersecurity.center/ (Maritime Cyber-bersecurity Center); virtual center dedicated to 
research and development of the concept of maritime medicine in the virtual environment http://www.emaritimemedicine.net (E-Maritime Medicine Center); annals with Scientometric Indexing, Anelis + Integration http://annals.cmuedu.eu; management system for examination sessions in UMC https://campus.cmuedu.eu/course/view.php?id=1215; Cyber Security Center https://www.maritimecybersecurity.center (Marine-based CyberSecurity Training Center);

- scientific events: the International Student Scientific Session (May 2017); the national phase of the "Traian Lalescu" competition (May 2017); the $5^{\text {th }}$ edition of the international conference Modern Technologies in Industrial Engineering (MODTECH) in cooperation with the Technical University of Iasi (June 2017); Maritime Cyber Security international conference, the first time in Romania, partners BIMCO, BSFA, IMO, Lloyds, INTERPOL, Deloitte, ABS, BitDefender, Check Point (March 2017).

Mircea Cel Bătrân Naval Academy from Constanţa The activity of the scientific research community within "Mircea Cel Bătrân Naval Academy from Constanţa" materialized in 2017 in the following results:

- projects won by competition: at the MApN (Ministry of National Defense) level, 8 projects in the Sectoral Development Plan PSCD, respectively at the end of the budgetary year, $8 / 8$ finalized, total value 26000 lei;

- scientific events: the $7^{\text {th }}$ edition of the Master's Degree Session of Scientific Communications MASTERNAV 2017 (9-10 May) - The conference was organized on 3 areas of research, with a total of 46 participants from the "Mircea Cel Bătrân Naval Academy from Constanţa" and "Ovidius University in Constanta", with 46 papers; the $39^{\text {th }}$ edition of the CADET-NAV 2017 Student Scientific Session (4-6 June) - This scientific event was attended with more than 320 papers, by 282 students from 12 national and foreign military and civilian centers with which "Mircea Cel Bătrân Naval Academy from Constanţa"collaborates; the $3^{\text {rd }}$ Conference of the International Conference SEA-CONF 2017 (18-20 May) - The conference took place on 8 sections (Transport, Ship Equipment, Electrical Engineering, Mechanical Engineering, Military Sciences, Economics, Management and Logistics and Environment, in which there were registered 178 participants with 124 papers; Graduate Session (22-23 June) at department level; the $5^{\text {th }}$ edition of the national workshop AGIR "Research and Engineering Expertise in Constanta" (November 1 $7^{\text {th }}$ ) - The theme of the edition: "Innovation and creativity in the knowledge society";

- publications: 5 ISI Proceedings articles (Category A); 62 BDI articles; 1 scientific paper participating in international inventions salons; 16 representation activities; 13 published books recognized by CNCSIS;

- national or international development projects (POSDRU, POS, LLP, etc.) - ANELIS PLUS CAPACITIES ctr. 420/2013, UEFISCDI-ANMB Partner. PNCDI II-CNMP Program, 2016-2020, total value of project 33259 euro, access to 3 international databases;

- participation in research grants, research / development: (EU-Interregio funds, EFTA, HORIZON 2020, grants, various international calls, international collaboration contracts) - 3 ongoing contracts and 1 proposed project to be submitted; (financed by the Romanian Government - POC, POCU, POIM, ROP or funds through the National RDI Plan - PNCDI) - 1 contract in progress and 2 proposed projects to be submitted or applied projects.

The advanced, fundamental and applied research is carried out at the level of Galaţi County in the two university centres: "Dunărea de Jos University", belonging to the public sector and "Danubius University", representing the private higher education sector.

\section{Dunărea de Jos University of Galați}

"Dunărea de Jos University of Galaţi" promotes the development of a research environment centered on technological progress and innovation, competitive at national and international level. At the university level there are 38 research units, out of which 35 at the level of the 14 faculties, and 3 at the university level. They operate in 6 fundamental areas, as follows: 23 in Engineering Sciences; 5 in Mathematics and Natural Sciences; 2 in Biological and Biomechanical Sciences; 7 in Humanities and Arts; 6 Social Sciences; and 1 in Science of Physical Education and Sport.

The members of the "Dunărea de Jos" academic community participated with project proposals in open competitions in various programs, the total number of projects being developed in 2017 being 130, the university being the coordinator ( 20 projects); partner (33 projects) and single beneficiary ( 77 projects). The total amount of funds attracted was 8460434 lei; 312916 euro and 3650 USD.

The results of research, development and innovation, the arts and sports performance in 2017, fall into the following categories:

- scientific contributions published or presented at scientific events: 187 articles published in WOS rated magazines; 27 articles published in WOS-indexed magazines; 135 articles published in ISI Proceedings; 536 articles published in BDI journals; 1104 papers presented at national and international conferences, of which 720 were presented orally and 384 as poster;

- 82 titles and 2244 pages in book chapters published in national publishing houses; 
- 13 titles and 1254 pages in book chapters published in international publishing houses;

- 6 patents granted by OSIM (State Office for Inventions and Trademarks) by Government Decision;

- 11 patent applications filed with OSIM;

- sport performance: The students of the Faculty of Physical Education and Sports, under the guidance of the faculty, have achieved outstanding results in the national and international competitions they participated in, as follows: 27 times - $1^{\text {st }}$ place, 20 times $-2^{\text {nd }}$ place, 14 times $-3^{\text {rd }}$ place. Other top performances: winning the Romanian Hockey Cup with the "CSM Danube Galati" team; $4^{\text {th }}$ and $9^{\text {th }}$ place at the World Dance Championships held in Chişinău (Moldova) and Marseille (France); Promote the motor evaluation for admission to the Bucharest Police Academy and the Military Medicine Institute from Tg. Mureş of 7 athletes trained at the Fitness Center of "Dunarea de Jos University in Galati";

- artistic creation: 143 events specific to the Faculty of Arts, out of which 18 plays in national theater performances, as well as 1 role in a feature film with international distribution, whose premiere took place in Paris. The award for "Best Comedy Performance" and "Best Dramaturgy" for the Theater Settlement "Privacy Settings" by Radu Horghidan, directed by Radu Horghidan, Social Act Theater Association, that was presented at the Independent Theater Marathon Festival, in Bucharest in 2017.

The faculties of "Dunărea de Jos University of Galaţi" organized in 2017 a total of 162 scientific events, out of which 26 events with international participation.

The Student Scientific Session, a student-centered event, held annually during May in the "Dunărea de Jos University of Galaţi", was finalized in 2017 by awarding 192 prizes with a total value of 22400 lei, following the evaluation of 1866 works scientific papers presented in 66 sections of all faculties.

The Conference of Doctoral Schools reached the $5^{\text {th }}$ edition in 2017 and was held on 7 sections (http://www.cssd-udjg.ugal.ro), the research-paper being published in various specialized journals.

\section{Danubius University of Galati}

The visibility and active role of the "Danubius University of Galati" in the field of research-development-innovation, at the level of 2017, materialized in the following results:

- publication of monographs and own course notes - 29 titles;

- conducting consultations and roundtables with business partners and other community stakeholders: 3 round tables on the development pole Galati-Braila; round table "Facebook"; round table "Good Administration. Principles and Best Practices"; information seminar "Good Practices in Writing an
Indexed Web Page of Science"; practical seminar on access to the EBSCO and EBSCO eBooks database; workshop in collaboration with One World Romania and the high schools in Galati, "Film Club"; information seminar "Deontology and Communication of Science"; workshop in collaboration with the high schools in Galati "Minorities in the context of international security";

- integration of students and master students into scientific research activity (http://www.conferences.univdanubius.ro/index.php /EIRP/EIRP2017/schedConf/presentations?searchFi eld $=\&$ searchMatch $=\&$ search $=\&$ track=158) $\quad-\quad 22$ student communications within EIRP 2017;

- publishing scientific journals in the platform Danubius Journals - 8 journals;

- publication of the volume of the annual EIRP conference $-12^{\text {th }}$ edition;

- publication of the volume of the DAIE annual conference - VII edition;

- publishing the volume of the AUAP 2017 conference;

- promoting Danubius research abroad: "Researcher Profile" webpage; the SOCED database;

- identifying and promoting new scientific fields in line with market realities of the modern scientific world and the major goals at national and European level one publication in Psychology, author Susanu Neaga.

The extenso results on the scientific research activity of Danubian community members are published on the dedicated website of the institution at:

http://evidentacercetare.univ-

danubius.ro/Cercetare $\% 20$ stiintifica.htm

\section{Conclusions and recommendations}

The socio-economic development at regional level is determined by the existence and development of Smart University, as institutions of knowledge, which plays a key role in generating human capital (through education system), technological progress (through research), but also in the formulation and implementation of government policies for local and regional development.

The intense competition, triggered by the globalization process, transcends regional space, which implies increasing adaptability and flexibility in order to cope with the pressures generated by market dynamics and rapid and continuous transformations in the information technology segment. Education and research exert a major contribution to this process. Knowledge, learning mechanisms and channels for the dissemination of knowledge flows and good practices contribute significantly to the development of human capital, capacity building and performance of local firms, diversification of services, improve of technical infrastructure and, overall 
create favourable conditions for economic expansion at regional level.

The position of universities in the process of regional development has changed significantly over time, transcending the stage of higher education institutions specialized in the creation and transfer of knowledge to Smart University, whose strategic plan is to catalyse all stakeholders in the development process of the community. In other words, in this changing world a Smart University is the University of the Future, which prepares future students for future jobs.

The offer of HEIs in the South-East region is quite varied, covering a wide range of specializations that can provide the professional training of students. But in order to address the challenges of the $21^{\text {st }}$ century, we must ensure that adequate resources (human, technical and financial) exist in the university environment, in line with developmental ambitions. For these reasons, in order to be able to effectively address societal challenges, a Smart University, as a science and innovation center of the region, needs adequate funding. The positive effect of investments in the university environment will be felt in the long-run and will be propagated at the level of the entire regional community.

The segment of R\&D and innovation is also well represented at the level of the two major university centers - Constanta and Galati, the responsiveness of HEIs to regional development needs, having a relatively high potential. But, also in this direction, funding is a precondition for exploiting untapped opportunities, the material basis being essential for the university environment to be able to carry out its planned actions. On the other hand, the extent of surplus value that can make EU funding for research and innovation must be exploited, but considering both, the regional development needs and peculiarities, as well as the pressing challenges of the community, results that matter in people's lives.

Integrated territorial development requires effective strategies to respond to societal challenges with a regional dimension, and, consequently investment in HEIs cannot operate in isolation from the broader socio-economic context at regional level. Therefore, funding for the Smart University as a promoter of innovation must be carried out at central level, but also through the involvement of relevant stakeholders at regional level.

We also consider opportune to develop inter-university collaboration at the intra-regional level in order to identify optimal solutions for community problems, the exchange of ideas and good practices being viable mechanisms for promoting regional development. The active participation of HEIs in the life of the local community is a prerequisite for regional development, but also a habit to cultivate, in order for the socio-economic impact to be real and tangible.

\section{Acknowledgements.}

This article draws on the research presented within the framework of the project: "Strategic Framework for Education Infrastructure and Support Strategic Planning of Education and Training INFRAED" under Operational Program Administrative Capacity
2014-2020, code SIPOCA 6 - REAP Update (The Regional Action Plan for Education), Higher Education sections for SouthEast Region of Romania.

\section{References}

[1] Georgescu, L. Raportul anual al rectorului privind starea universității - 2017 [University Rector's Annual Report on the State of the University - 2017]. Galati: Universitatea "Dunărea de Jos" din Galati, 2018.

[2] Government Decision no. $185 / 2018$ on university studies fields and accredited master's degree programs programs and on the maximum number of students that can be enrolled in the academic year 2018-2019, Official Gazette number 323 of April 12, 2018.

[3] Government Decision no. 692/2018 for the amendment and completion of the Government Decision no. 158/2018 regarding the approval of the Domain Nomenclature and others specializations / programs of university studies and the structure of HEIs for the academic year 2018-2019, Official Gazette number 786 of September 13, 2018,

[4] Kitchen, H., Fordham, E., Henderson, K., Looney, A., Maghnouj, S.. Romania 2017. OECD Reviews of Evaluation and Assessment in Education. Paris: OECD Publishing, 2017, available at: http://dx.doi.org/10.1787/9789264274051-en

[5] Panait, C. Raport anual al rectorului Universităţii Maritime din Constanţa, pentru anul 2017. [Annual Report of the Rector of the Maritime University of Constanta for 2017]. Constanţa: Universitatea Maritimă din Constanţa, 2018.

[6] Petrescu, I., Gogu, E.: Oferta sistemului de învățământ superior românesc, Anul universitar 2016/2017 [The supply of the Romanian higher education system, academic year 2016/2017]. Bucuresti: ARACIS, 2017. available at:

http://www.aracis.ro/publicatii/publicatii-aracis/

[7] Pusca A.: Raport privind starea Universității Danubius din Galați în anul universitar 2016 - 2017. [Report on the state of Danubius University in Galaţi in the academic year 2016 - 2017] Galati: Universitatea Danubius din Galaţi, 2018.

[8] Rugină, S. Raportul rectorului privind starea Universității „Ovidius” din Constanța în anul 2017. [Rector's report on the state of Ovidius University in Constanta in 2017], Constanța, Universitatea Ovidius din Constanța, 2018.

[9] Tărăbuță, O.: Raport privind starea anuală a Academiei Navale "Mircea Cel Bătrân", 2017 [Annual report on the state of the "Mircea cel Batran" Naval Academy, academic year 2016/2017]. Constanța: Academia Navală "Mircea Cel Bătrân”, 2018. 